\title{
Do Excessive Legal Standards Discourage Desirable Activity?
}

\section{Citation}

Steven M. Shavell, Do Excessive Legal Standards Discourage Desirable Activity?, 95 Econ. Letters 394 (2007).

\section{Published Version}

http://dx.doi.org/10.1016/j.econlet.2006.11.013

\section{Permanent link}

http://nrs.harvard.edu/urn-3:HUL.InstRepos:12027788

\section{Terms of Use}

This article was downloaded from Harvard University's DASH repository, and is made available under the terms and conditions applicable to Other Posted Material, as set forth at http:// nrs.harvard.edu/urn-3:HUL.InstRepos:dash.current.terms-of-use\#LAA

\section{Share Your Story}

The Harvard community has made this article openly available.

Please share how this access benefits you. Submit a story.

\section{Accessibility}




\section{NELLCO}

\section{NELLCO Legal Scholarship Repository}

Harvard Law School John M. Olin Center for

Law, Economics and Business Discussion Paper

Harvard Law School

Series

2-4-2006

\section{Do Excessive Legal Standards Discourage Desirable Activity?}

Steven Shavell

Harvard Law School

\section{Recommended Citation}

Shavell, Steven, "Do Excessive Legal Standards Discourage Desirable Activity?" (2006). Harvard Law School John M. Olin Center for Law, Economics and Business Discussion Paper Series. Paper 540.

http://lsr.nellco.org/harvard_olin/540

This Article is brought to you for free and open access by the Harvard Law School at NELLCO Legal Scholarship Repository. It has been accepted for inclusion in Harvard Law School John M. Olin Center for Law, Economics and Business Discussion Paper Series by an authorized administrator of NELLCO Legal Scholarship Repository. For more information, please contact tracy.thompson@nellco.org. 
ISSN 1045-6333

\title{
HARVARD
}

JOHN M. OLIN CENTER FOR LAW, ECONOMICS, AND BUSINESS

\author{
DO EXCESSIVE LEGAL STANDARDS \\ DISCOURAGE DESIRABLE ACTIVITY?
}

Steven Shavell.

Discussion Paper No. 540

$2 / 2006$

Harvard Law School

Cambridge, MA 02138

This paper can be downloaded without charge from:

The Harvard John M. Olin Discussion Paper Series:

http://www.law.harvard.edu/programs/olin center/

The Social Science Research Network Electronic Paper Collection:

http://papers.ssrn.com/abstract_id=\#\#\#\#\# 
JEL codes: D00, H8, K13, K23, L5

\title{
Do Excessive Legal Standards Discourage Desirable Activity?
}

\author{
Steven Shavell*
}

\begin{abstract}
Overly strict legal standards are commonly thought to discourage parties from engaging in socially desirable activities. It is explained here, however, that excessive legal standards cannot lead to undesirable curtailment of activities when legal standards are enforced by liability for negligence, essentially because parties can choose to be negligent rather than comply. But excessive legal standards can lead to undesirable reduction of activities when adherence to the standards is required by the regulatory system.
\end{abstract}

Keywords: standards, regulation, liability, negligence.

* Samuel R. Rosenthal Professor of Law and Economics, Harvard University. I thank Louis Kaplow and A. Mitchell Polinsky for comments, Jared Gross and John Howell for research assistance, and the John M. Olin Center for Law, Economics, and Business at Harvard Law School for research support. 


\title{
Do Excessive Legal Standards Discourage Desirable Activity?
}

\author{
Steven Shavell \\ CC 2006 Steven Shavell. All Rights Reserved
}

\section{Introduction}

The question addressed in this note is whether overly strict legal standards tend to discourage parties from engaging in socially desirable activities. By legal standards, I refer generally to standards of precaution, investment in safety, and the like that must be met to avoid liability for negligence, ${ }^{1}$ as well as to regulatory standards that must be satisfied in order to participate in regulated activities. ${ }^{2}$ It seems to be a commonplace notion that unduly rigorous legal requirements may lead to too little socially beneficial activity, for instance, that excessive environmental standards can exert a disadvantageous chilling effect on business activity or that excessive duties of care can cause physicians to exit from socially desirable areas of medical practice. ${ }^{3}$

Perhaps surprisingly, the answer that is reached here is that inappropriately stringent legal standards cannot lead to socially undesirable discouragement of participation in activities when legal standards are enforced by liability for negligence. But excessive legal standards can lead to undesirable curtailment of activities when adherence to the standards is required by the regulatory system.

To explain, under the liability system, a party will be found negligent, and bear liability for any harm that it causes, if it fails to comply with a legal standard. As a consequence, if a legal standard is set too high (say the standard for investment in pollution control devices is more expensive than justified by the reduction in pollutionrelated harm that the devices accomplish), a party may well be led to satisfy the excessive standard in order to avoid liability for negligence. If so, just because the party will not be found negligent and not have to pay for harm that it causes, the party can be shown to participate to too great an extent in its activity, not too little. ${ }^{4}$ It is possible, though, that a legal standard will be set so high that a party will decide not to meet the standard (the called-for but unjustified pollution control devices are so expensive that they are not purchased) and thus will be held liable for negligence and have to pay for harm done. Yet in this case, the party will be led to take optimal (rather than excessive) precautions and to participate optimally in its activity, because it will pay for the harm that it causes. In sum, although parties may be led to take excessive precautions by excessive legal standards, they are never led to participate too little in their activities, and they might participate too much.

${ }^{1}$ The major basis of liability for harm in our legal system is liability for negligence, that is, failing to meet a legal standard; see, for example, Dobbs (2000), chapters 6, 11, and 23.

${ }^{2}$ For a general desciption of regulation, see, for example, Viscusi, Harrington, and Vernon (2005).

${ }^{3}$ This is one of the themes advanced in, for instance, Huber and Litan (1991).

${ }^{4}$ In Shavell (1980), I emphasized the general point that if parties obey a legal standard and thus avoid negligence liability, they do not pay for the harm they cause and thus tend to engage in activities to a socially excessive extent. However, I did not consider behavior under excessive legal standards or compare participation in activities under liability and under regulation. 
Under regulation, in contrast, there can be an undesirable chilling effect on participation in a regulated activity, assuming that parties are forced to comply with the legal standard in order to engage in the activity. If the legal standard is sufficiently burdensome, it will discourage some socially desirable participation in the activity.

The difference between the regulatory context and the negligence liability context is that only in the latter context can the party facing excessive legal standards choose not to adhere to the standards and instead pay for harm that eventuates.

\section{The model}

Let $x \geq 0$ be the level and cost of precautions taken by risk-neutral parties when they engage in a potentially harmful activity, and let $h(x)>0$ be the expected harm given $x$, where $h^{\prime}(x)<0$ and $h^{\prime \prime}(x)>0$. Let a party's level of the activity be $y \geq 0$. When a party engages in the activity at level $y$, assume that it derives a profit or private benefit $b(y)>0$, where $b^{\prime}(y)>0$ and $b^{\prime \prime}(y)<0$. Further, assume that the costs of precautions and expected harm rise in proportion to the level of activity - they equal $y(x+h(x))$ - the interpretation being that each time a party engages in the activity, it exercises precautions and may cause harm.

Suppose that social welfare equals private benefits minus the costs of precautions and expected harm, (1) $b(y)-y(x+h(x))$.

Hence, the socially optimal level of precautions, denoted $x^{*}$, minimizes $x+h(x)$. Further, the socially optimal level of activity, denoted $y^{*}$, is determined by the first-order condition $^{5}$

(2) $b^{\prime}(y)=x^{*}+h\left(x^{*}\right)$,

namely, the marginal private benefit from engaging in the activity equals the marginal social costs, comprised of the costs of optimal precaution and the expected harm generated each time the activity is undertaken.

Consider now liability for negligence, under which a legal standard of precautions is set, denoted $s$. We will consider different possible standards. ${ }^{6}$ By definition of the negligence rule, if a party's level of precaution $x$ is at least $s$, it will not be found negligent and will not be made to pay for harm caused, whereas if $x$ is less than $s$, it will be found negligent and will thus bear $h(x)$. What $x$ will a party select? Clearly, a party will never choose $x$ exceeding $s$, for it will escape liability by exercising merely $s$. If the party chooses $x$ below $s$, its expected expenses will be $x+h(x)$. Hence, it will choose $s$ as long as

(3) $s \leq x+h(x)$ for all $x<s$.

It follows from (3) that a party will choose $s$ if $s$ in the interval $\left[0, s_{m}\right]$, where ${ }^{7}$

\footnotetext{
${ }^{5}$ For simplicity, I assume that $y^{*}$ is positive, so that (2) must hold.

${ }^{6}$ The motivation is that the court (or, below, the regulator) may not have sufficient information to calculate the optimal level of precaution $x^{*}$ and to set the legal standard $s$ equal to it. For my purposes, there is no need to consider the court's information and its choice of $s$. My interest is in determining parties' behavior as a function of $s$.

${ }^{7}$ Since $x *$ minimizes $x+h(x)$ over all $x$, the right-hand side of (3) is greater than or equal to $x^{*}+$ $h\left(x^{*}\right)=s_{m}$. Hence (3) must hold for $s \leq s_{m}$.
} 
(4) $s_{m}=x^{*}+h\left(x^{*}\right)$.

In other words, parties will satisfy the legal standard $s$ if it does not exceed the socially optimal standard $x^{*}$ by too much (more than $h\left(x^{*}\right)$ ). But if $s>s_{m}$, parties will prefer to be negligent than to satisfy the standard: If a party is negligent, it will choose $x^{*}$ (as it will choose $x$ to minimize $x+h(x))$ and bear total expenses of $x^{*}+h\left(x^{*}\right)=s_{m}<s$. Further, when $s<s_{m}$, since parties choose $s$, their cost of participation is just $s$ per unit, so they choose $y$ to maximize

(5) $b(y)-y s$,

and thus their $y$ is determined by

(6) $b^{\prime}(y)=s$,

so that their choice of $y$ is excessive; $y>y^{*}{ }^{8}$ The explanation is that their cost per unit of activity leaves out the harm $h(s)$, so they do not face the appropriate social cost of engaging in the activity. However, if the legal standard is sufficiently excessive, at least $s_{m}$, they will choose $y^{*}$ since they will then choose $x^{*}$ and bear $h\left(x^{*}\right)$. We can summarize as follows.

Proposition 1. Under the negligence rule, parties choose precaution $x$ equal to the legal standard $s$ if $s$ does not exceed $s_{m}=x^{*}+h\left(x^{*}\right)$, namely, optimal precaution plus expected harm per unit of activity; but parties decide to be negligent and to choose optimal precaution if $s$ exceeds $s_{m}$. Parties' level of activity $y$ is socially excessive ( $y>$ $\left.y^{*}\right)$ if $s<s_{m}$ and is optimal for $s$ at least $s_{m}$. In particular, parties' level of activity is never too low.

Note that although any legal standard $s$ in the interval $\left(x^{*}, x^{*}+h\left(x^{*}\right)\right)$ is excessive and results in excessive precaution, it also leads to excessive levels of activity rather than to too little activity.

Now consider regulation and legal standards assuming that parties must comply with a legal standard in order to participate in the activity. Then, since parties who participate in the activity take precautions equal to $s$, whatever $s$ is, their level of activity is determined by (6) regardless of $s$. If $s>s_{m}$, their activity level $y$ will thus be too low, less than $y^{*}$. To be explicit, we have

Propostion 2. Under regulation, in which parties must meet the legal standard $s$, parties' level of activity $y$ is socially excessive $\left(y>y^{*}\right)$ if $s<s_{m}$, optimal if $s=s_{m}$, and too low if $s>s_{m}$.

The difference between regulation and negligence liability is, as stated above, that when the legal standard is very high - exceeding $s_{m}$ - it must be satisfied under regulation, and hence leads to a too low level of activity, whereas under negligence liability, parties can and will choose to ignore the excessive standard and will behave optimally. Note too that, under regulation, even when the legal standard $s$ is high enough to depress the activity $y$ to below the optimal level $y^{*}$, the level of activity is still excessive conditional on the level of precaution $s$.

\section{Conclusion}

The familiar notion that unduly strict legal standards undesirably curb participation in socially desirable activities needs to be cautiously interpreted. There is, to begin with, an underlying tendency for parties to engage too much in activities under the negligence rule of liability and under regulation, because complying parties do not

\footnotetext{
${ }^{8}$ This follows because $s<s_{m}=x^{*}+h\left(x^{*}\right)$ and because $b^{\prime \prime}(y)<0$.
} 
bear the harm that their activities generate. Moreover, under liability for negligence, parties have the option, the escape hatch, of acting negligently rather than complying with a harsh legal standard. Hence, it turns out that under negligence liability, parties never engage too little in their activities. ${ }^{9}$ Under regulation, however, parties may be undesirably discouraged from participating in their activities if standards are excessive, given the assumption they must comply with the standards.

${ }^{9}$ However, if the level of damages that parties pay if found negligent exceeds harm (because, for instance, punitive damages are imposed), the conclusion might be different. 


\section{References}

Dobbs, Dan B. 2000. The Law of Torts. St. Paul, Minn.: West Group.

Huber, Peter W., and Robert E. Litan, editors. 1991. The Liability Maze: The Impact of Liability Law on Safety and Innovation. Washington, DC: Brookings Institution.

Shavell, Steven. 1980. "Strict Liability versus Negligence.” Journal of Legal Studies, 9(1), pp. 1-25.

Viscusi, W. Kip, Joseph E. Harrington, Jr., and John M. Vernon. 2005. Economics of Regulation and Antitrust. Fourth edition. Cambridge, Mass.: MIT Press. 